\title{
High C-Reactive Protein/Albumin Ratio Increased Risk of Acute Malnutrition During Hospitalization in Pediatric Patients
}

\author{
(D) crossark \\ I Gusti Lanang Sidiartha ${ }^{a}$, Dyah Kanya Wati ${ }^{b}$, Ida Bagus Subanadac, I Gusti Ngurah Made Suwarbad \\ Manuscript submitted: 18 August 2020, Manuscript revised: 27 September 2020, Accepted for publication: 09 October 2020
}

\section{Corresponding Author a}

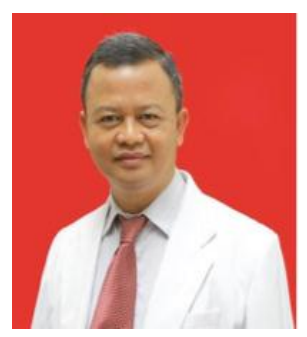

Keywords

albumin;

CRP;

inflammation;

malnutrition;

pediatric;

\begin{abstract}
Pediatric patients with malnutrition commonly have poor prognosis related to the inflammation and catabolism state. This study investigated the relationship between high C-Reactive Protein/Albumin ratio on admission with the risk of acute malnutrition during hospitalization in pediatric patients. A cohort study in patients aged 1 month to 18 years old who met the study criteria was done. On admission, the level of serum C-Reactive Protein and Albumin were measured and calculated the C-Reactive protein/Albumin ratio which was divided into the high and low ratio. Acute malnutrition was determined according to the weightfor-height or body mass index-for-age z-score less than 2 SD below the WHO Child Growth Standard median. A total of 110 patients were analyzed, 50\% male and the mean aged was 77.7 months. Patients with acute malnutrition on admission and discharge were $24.5 \%$ and $32.7 \%$, respectively. Acute malnutrition on discharge in patients with high and low ratio were $51.6 \%$ and 25.3\%, respectively (adjusted Relative Risk, 9.1; 95\% CI: 1.9 to 42.7; $\mathrm{p}=0.005$ ). High C-Reactive Protein/Albumin ratio on admission increased the risk of acute malnutrition during hospitalization in pediatric patients.
\end{abstract}

International Journal of Health Sciences (C) 2020. This is an open access article under the CC BY-NC-ND license (https://creativecommons.org/licenses/by-nc-nd/4.0/). 


\section{Introduction}

Pediatric patients with malnutrition commonly have a poor prognosis, such as a length of hospital stay, higher hospital cost, increased severity of the diseases, and finally higher rates of mortality (León-Sanz et al., 2015; Suriadji et al., 2107; Artawan et al., 2016; Sudarmadji et al., 2016). This condition needs more attention from the pediatrician to ensure optimal nutrition support in pediatric patients during hospitalization. The prevalence of pediatric malnutrition in hospitals is still quite high, range from $23.7 \%$ to $52.7 \%$ (Kapçi et al., 2015; Mărginean et al., 2014). In our hospital, malnutrition in pediatric patients during hospitalization is also still high, although it decreases from 30.1\% in 2008 to $17.5 \%$ in 2012 (Sidiartha, 2016; 2012). Each pediatrician requires to pay serious attention to prevent and treat malnutrition in pediatric patients during hospitalization.

The inflammatory process is one reason why malnutrition during hospitalization in pediatric patients is still high. It causes loss the appetite and inadequate nutrition intake. On the other hand, it increases the catabolism state that increasing the nutrition requirement. Both inadequate nutritional intake and increased nutrition requirement cause acute malnutrition during hospitalization which is characterized by weight loss during the hospital (Kaysen, 2006; Gomes de Lima, 2012). Weight loss decreases weight-for-height (W/H) or body mass index-for-age (BMI/A) z-score which is known as an indicator of acute malnutrition in pediatrics (Guide, 2012). C-reactive protein (CRP) is known as a biomarker of inflammation which is a high level of CRP related to high risk of malnutrition during hospitalization (World Health Organization, 2014). Albumin is known as a biomarker of anabolism and it is used as an indicator of nutritional status, particularly in pediatric patients. The catabolic state in pediatric patients during hospitalization decreases serum Albumin levels (Gomes de Lima, 2012; Gualillo et al., 2000; Bonn \& Driscoll, 1996).

Several studies have reported the relationship of CRP/Albumin ratio on prognosis and mortality rates of several diseases, but not on the risk of acute malnutrition (Ventura et al., 2018; Mohamed \& Elhawary, 2020; Li et al., 2017). This current study investigates the relation between CRP/Albumin ratio on admission with the risk of acute malnutrition during hospitalization in pediatric patients.

\section{Materials and Methods}

The design of this study was an observational cohort prospective approach. Pediatric patients who met the study criteria were recruited in the first 24 hours of admission and then followed until discharge. The relationship between $\mathrm{CRP} /$ Albumin ratio on admission and the incidence of acute malnutrition on discharge were analyzed (Doumas et al., 1997).

This study was conducted in a single-center teaching hospital in Bali, Indonesia. All pediatric patients aged 1 month to 18 years old who were admitted at Pediatric Ward, Sanglah General Hospital, a tertiary referral hospital in Indonesia, from May to September 2019 who met the study criteria were recruited. All parents agreed to participate by signing the informed consent. Patients were excluded if discharged within 48 hours, admitted in intensive care units, severe edema, organomegaly, and readmitted during the study period. The Ethical Committee of Medical Faculty, Udayana University - Sanglah General Hospital, Denpasar, Bali, Indonesia approved this study with No. 1473/UN14.2.2.VII.14/LP/2019.

At admission, age, gender, body weight, body height, and laboratory data (serum CRP and Albumin) were investigated. Bodyweight with light clothes as much as possible was measured early in the morning, before breakfast. This procedure was repeated on the last day of hospitalization, before discharge. At the same time, body height or length was measured without shoes using a stadiometer or longboard at admission and discharge. The Z-score of weight-for-height $(\mathrm{W} / \mathrm{H})$ and Body Mass Index-for-age (BMI/A) were calculated. The BMI calculation is based on body weight in $\mathrm{kg}$ divided by height in meter square $(\mathrm{kg} / \mathrm{m} 2)$. Acute malnutrition was defined if W/H (aged < 5 years) or BMI/A ( $>5$ years) less than 2 SD below the WHO Child Growth Standard median. Serum CRP and Albumin levels were measured using immune-turbidimetry and calorimetry

Sidiartha, I. G. L., Wati, D. K., Subanada, I. B., \& Suwarba, I. G. N. M. (2020). High C-reactive protein/albumin ratio increased risk of acute malnutrition during hospitalization in pediatric patients. International Journal of Health Sciences, 4(3), 32-38. https://doi.org/10.29332/ijhs.v4n3.453 
methods, respectively. The CRP/Albumin ratio was determined with CRP level divided by serum Albumin and then divided into two groups that were "high" and "low" according to the upper and below of the median value, respectively (Lawson et al., 2001; Cabrera et al., 2007).

The minimal sample size was 92 according to $\alpha 0.05$ ( $\mathrm{Z} \alpha 1.96$ ), power $80 \%$, the prevalence of hospital malnutrition before $30 \%$, and the effect size of $20 \%$. The relation between the CRP/Albumin ratio at admission and acute malnutrition on discharged was analyzed using the Chi-Square test. Multiple logistic regression test was used to adjusted variables including age, gender, underlying diseases, nutrition support, and nutritional status at admission. Significance was considered if $\mathrm{P}$-value $<0.05$.

\section{Results and Discussions}

During the study period, from May to September 2019, a total of 132 patients were recruited, and among them, 110 patients have met the study criteria (Figure 1). From 110 patients, 55 males, and 55 females with a mean aged of 77.7 months. Patients with acute malnutrition on admission and discharge were $24.5 \%$ (27 of 110 patients) and 32.7\% (36 of 110 patients), respectively. The underlying disease of patients was mostly an acute infection (57.3\%) and dominantly supported by oral or enteral nutrition (94.5\%). Patients with high and low CRP/Albumin ratio were $28.2 \%$ and $72.8 \%$, respectively.

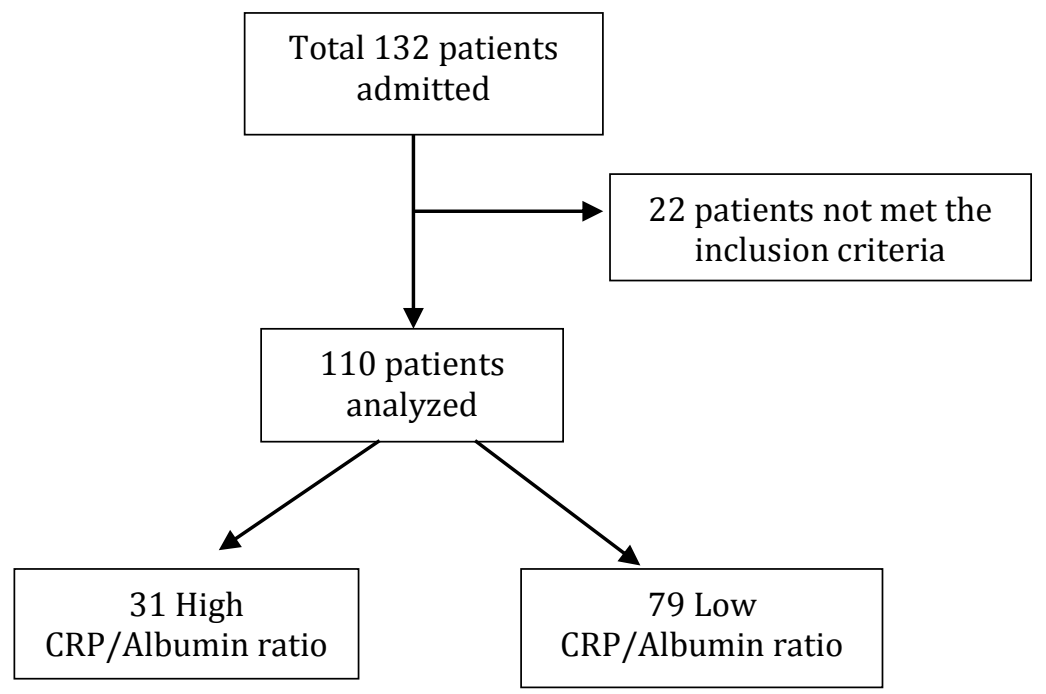

Figure 1. Flow chart selection of pediatric patients

Table 1 showed the characteristics of all patients. An acute malnutrition in patients with high and low CRP/Albumin ratio were $32.3 \%$ and $21.5 \%(p=0.239)$ on admission and $51.6 \%$ and $25.3 \%(p=0.008)$ on discharge, respectively (Table 2). The relation of CRP/Albumin ratio with acute malnutrition on discharge after adjusted with variables, such as age, gender, and nutritional status was shown in Table 3. 
Table 1

The general characteristic of patients

\begin{tabular}{ll}
\hline Characteristic & $\mathrm{N}=110$ \\
\hline Gender, male:female (n:\%) & $55: 55(50: 50)$ \\
\hline Age (month), mean \pm SE & $77.7 \pm 6.5$ \\
\hline Weight (kg), mean \pm SE & $22.1 \pm 1.6$ \\
\hline Height (cm), mean \pm SE & $107 \pm 3.5$ \\
\hline Acute malnutrition on admission, $\mathrm{n}(\%)$ & $27(24.5)$ \\
\hline Acute malnutrition on discharge, $\mathrm{n}(\%)$ & $36(32.7)$ \\
\hline Albumin $(\mathrm{g} / \mathrm{dL})$, mean $\pm \mathrm{SE}$ & $3.42 \pm 0.07$ \\
$\quad$ Albumin $<3.5 \mathrm{~g} / \mathrm{dL}, \mathrm{n}(\%)$ & $50(45.5)$ \\
\hline CRP $(\mathrm{mg} / \mathrm{L})$, mean $\pm \mathrm{SE}$ & $13.42 \pm 2.66$ \\
CRP $>10$ mg/L, $\mathrm{n}(\%)$ & $41(37.3)$ \\
\hline CRP/Albumin ratio, mean $\pm \mathrm{SE}$ & $4.87 \pm 0.91$ \\
High (> 4.87), $\mathrm{n}(\%)$ & $31(28.2)$ \\
\hline Underlying disease & \\
Acute infection, $\mathrm{n}(\%)$ & $63(57.3)$ \\
Chronic infection, $\mathrm{n}(\%)$ & $11(10.0)$ \\
$\quad$ Non-infection, $\mathrm{n}(\%)$ & $36(32.7)$ \\
\hline Nutrition support & $104(94.5)$ \\
Oral/Enteral, $\mathrm{n}(\%)$ & $6(5.5)$ \\
Parenteral, $\mathrm{n}(\%)$ &
\end{tabular}

CRP, c-reactive protein; SE, standard error

Table 2

The relation between CRP/Albumin ratio with acute malnutrition

\begin{tabular}{|c|c|c|c|c|c|c|c|c|}
\hline \multirow{2}{*}{$\begin{array}{l}\text { CRP/Albumin } \\
\text { ratio }\end{array}$} & \multicolumn{4}{|c|}{ Acute malnutrition on admission } & \multicolumn{4}{|c|}{ Acute malnutrition on discharge } \\
\hline & yes & no & RR (95\%CI) & $\mathrm{P}^{*}$ & yes & no & RR (95\%CI) & $\mathrm{P}^{*}$ \\
\hline High, $n(\%)$ & $10(32.3)$ & $\begin{array}{c}21 \\
(67.7)\end{array}$ & $\begin{array}{c}1.5(0.8- \\
2.9)\end{array}$ & 0.239 & $\begin{array}{c}16 \\
(51.6)\end{array}$ & $\begin{array}{c}15 \\
(48.4)\end{array}$ & $2.3(1.2-3.4)$ & 0.008 \\
\hline Low, n(\%) & $17(21.5)$ & $\begin{array}{c}62 \\
(78.5)\end{array}$ & & & $\begin{array}{c}20 \\
(25.3)\end{array}$ & $\begin{array}{c}59 \\
(74.7)\end{array}$ & & \\
\hline
\end{tabular}

CRP, c-reactive protein; RR, relative risk; ${ }^{*}$ Chi-Square test

Table 3

Multivariate analysis logistic regression

\begin{tabular}{lccc}
\hline Variable & $\operatorname{Exp}(\mathrm{B})$ & $95 \% \mathrm{CI}$ for $\operatorname{Exp}(\mathrm{B})$ & $\mathrm{P}$ \\
\hline High ratio & 9.1 & $1.9-42.7$ & 0.005 \\
Male gender & 1.7 & $0.3-7.9$ & 0.450 \\
Aged & 1.0 & $0.9-1.0$ & 0.315 \\
Acute malnutrition on admission & 430.9 & $34.8-5322.8$ & 0.0001 \\
Acute infection & 1.9 & $0.7-4.9$ & 0.151 \\
Oral/enteral nutrition & 0.8 & $0.1-36.3$ & 0.921 \\
\hline
\end{tabular}

This current study found the prevalence of acute malnutrition based on W/H or BMI/A z-score less than 2 SD below the WHO Child Growth Standard median on admission was $24.5 \%$ and it increased to become $32.7 \%$ on discharge. The increase of malnutrition during hospital in pediatric patients has been known as related to many factors such as the underlying diseases and nutrition support during hospitalization.[16] The

Sidiartha, I. G. L., Wati, D. K., Subanada, I. B., \& Suwarba, I. G. N. M. (2020). High C-reactive protein/albumin ratio increased risk of acute malnutrition during hospitalization in pediatric patients. International Journal of Health Sciences, 4(3), 32-38. https://doi.org/10.29332/ijhs.v4n3.453 
underlying diseases of our patients were a mostly acute infection that commonly mild to moderate in severity. Nutrition support in most patients was oral or enteral that closely $94.5 \%$. Both of them were not significantly different in this study. So, based on this underlying disease and the type of nutrition support maybe though a little bit impact on the increase of malnutrition in these patients.

The inflammatory process and nutritional status according to the high levels of serum CRP and low levels of Albumin should be considered related to the acute malnutrition. This study found that a total of $37.3 \%$ of patients have serum CRP levels of more than $10 \mathrm{mg} / \mathrm{L}$ which was related to inflammation and risk of malnutrition. On the other hand, the serum albumin levels less than $3.5 \mathrm{~g} / \mathrm{dL}$ was found in $45.5 \%$ of total patients. Albumin has been known as an indicator of the nutritional status and low levels related to the risk of malnutrition, including in pediatric patients. This study combined the serum CRP and Albumin as a $\mathrm{CRP} /$ Albumin ratio to identified the risk of malnutrition during hospitalization in pediatric patients. In this study, the high CRP/Albumin ratio was found in a total of $28.2 \%$ of patients. At the end of the study, the rate of acute malnutrition in patients with a high CRP/Albumin ratio was significantly higher than in patients with low CRP/Albumin ratio (51.6\% vs 25.3\%). Along with our knowledge, this was the first study that investigated the relationship between CRP/Albumin ratio on admission with the risk of acute malnutrition during hospitalization in pediatric patients. Other studies reported the relationship between this ratio with the prognosis and mortality rates in patients with chronic diseases and critical illness (Ventura et al., 2018; Mohamed \& Elhawary, 2020; Li et al., 2017).

On one side, blood CRP as an acute-phase protein will increase in patients with infection as well as in noninfection as a response to the inflammatory process, on another side, Albumin as a negative acute-phase protein decrease. Thus, the high CRP/Albumin ratio indicates a high inflammatory process. Inflammation suppresses the patient's appetite causing inadequate nutrition intake and stimulates the increased energy requirement, resulting in malnutrition during hospitalization (Braun \& Marks, 2010). Pediatricians and nutritionists should pay more attention to this mechanism and give optimal nutrition support to prevent acute malnutrition during hospitalization, particularly in pediatric patients who still in growth and development processing.

Nutritional status on admission also influenced the risk of acute malnutrition during hospitalization, although it is still controversial. One study found that patients with malnutrition on admission had lost more BMI on discharge, but the other study found that patients with mild malnutrition had more a negative impact on the nutritional status during hospital stay compared with patients with moderate malnutrition (MAC, 2017). This study found that patients with acute malnutrition on admission have a higher risk to become malnutrition during hospital stay compared with patients with well-nourished. Both patients with or without malnutrition on admission should receive similar attention from the health care team to prevent malnutrition during the hospital stay.

The limitations of the study were not calculating the energy and other macro-nutrients intake during hospitalization that maybe influence the risk of acute malnutrition. The degree of severity of the underlying diseases was not differentiating, although this study excludes the patients in intensive care units. It may also influence the risk of acute malnutrition.

\section{Conclusion}

The study concludes a high CRP/Albumin ratio in pediatric patients on admission relates to the high rate of acute malnutrition during hospitalization. Routine measurement of serum CRP and Albumin in pediatric patients on the first admission day are recommended to predict the risk of malnutrition during hospitalization and plan optimal nutrition support. Further clinical trials are needed to find out the benefits of controlling serum CRP levels during hospitalization for improving nutritional status in pediatric patients.

\section{Acknowledgments}

Many thanks to participating children and their parents for participation. 


\section{References}

Artawan, A., Purniti, P. S., \& Sidiartha, I. L. (2016). Hubungan antara Status Nutrisi dengan Derajat Keparahan Pneumonia pada Pasien Anak di RSUP Sanglah. Sari Pediatri, 17(6), 418-22.

Bonn, P. J., \& Driscoll, K. (1996). Particles, inflammation and respiratory tract carcinogenesis. Toxicology letters, 88(1-3), 109-113. https://doi.org/10.1016/0378-4274(96)03725-3

Braun, T. P., \& Marks, D. L. (2010). Pathophysiology and treatment of inflammatory anorexia in chronic disease. Journal of cachexia, sarcopenia and muscle, 1(2), 135-145.

Cabrera, M. A. S., Mesas, A. E., Garcia, A. R. L., \& de Andrade, S. M. (2007). Malnutrition and depression among community-dwelling elderly people. Journal of the American Medical Directors Association, 8(9), 582-584. https://doi.org/10.1016/j.jamda.2007.07.008

Doumas, B. T., Watson, W. A., \& Biggs, H. G. (1997). Albumin standards and the measurement of serum albumin with bromcresol green. Clinica chimica acta,258(1), 21-30. https://doi.org/10.1016/S00098981(96)06447-9

Gomes de Lima, K. V., \& Maio, R. (2012). El estado nutricional, la inflamación sistémica y el pronóstico de los pacientes con cáncer gastrointestinal. Nutrición Hospitalaria, 27(3), 707-714.

Gualillo, O., Eiras, S., Lago, F., Diéguez, C., \& Casanueva, F. F. (2000). Elevated serum leptin concentrations induced by experimental acute inflammation. Life sciences, 67(20), 2433-2441. https://doi.org/10.1016/S0024-3205(00)00827-4

Guide, I. (2012). Interpretation Guide. Nutrition Landacape Information System. pp. 1-51.

Kapçı, N., Akçam, M., Koca, T., Dereci, S., \& Kapcı, M. (2015). The nutritional status of hospitalized children: Has this subject been overlooked. Turk J Gastroenterol, 26(4), 351-5.

Kaysen, G. A. (2006). Association between inflammation and malnutrition as risk factors of cardiovascular disease. Blood purification, 24(1), 51-55.

Lawson, J. A., Lazarus, R., \& Kelly, J. J. (2001). Prevalence and prognostic significance of malnutrition in chronic renal insufficiency.Journal of renal nutrition,11(1), 16-22. https://doi.org/10.1016/S10512276(01)85914-8

León-Sanz, M., Brosa, M., Planas, M., García-de-Lorenzo, A., Celaya-Pérez, S., \& Hernández, J. Á. (2015). PREDyCES study: The cost of hospital malnutrition in Spain. Nutrition, 31(9), 1096-1102. https://doi.org/10.1016/j.nut.2015.03.009

Li, Y. J., Yao, K., Lu, M. X., Zhang, W. B., Xiao, C., \& Tu, C. Q. (2017). Prognostic value of the C-reactive protein to albumin ratio: a novel inflammation-based prognostic indicator in osteosarcoma. OncoTargets and therapy, $10,5255$.

Mac, G. (2017). Hospital Malnutrition in Pediatric Patients: A Review. Annals of Nutritional Disorders \& Therapy, 4(2), 1042.

Mărginean, O., Pitea, A. M., Voidăzan, S., \& Mărginean, C. (2014). Prevalence and assessment of malnutrition risk among hospitalized children in Romania. Journal of health, population, and nutrition, $32(1), 97$.

Mohamed, S. A., \& ElHawary, R. (2020). C-Reactive Protein/Albumin Ratio as an Independent Predictor of Mortality in Critically Ill Pediatric Patients. Journal of Child Science, 10(01), e1-e11.

Sidiartha, I. G. L. (2012). Insidens malnutrisi rumah sakit pada anak di rumah sakit umum pusat Sanglah Denpasar. Medicina, 43, 15-8.

Sidiartha, I. G. L. (2016). Insidens malnutrisi rawat inap pada anak balita di Rumah Sakit Umum Pusat Sanglah Denpasar. Sari Pediatri, 9(6), 381-85.

Sudarmadji, S., Wati, D. K., \& Sidiartha, L. (2016). Faktor risiko pada lama rawat dan luaran pasien perawatan di unit perawatan intensif anak RSUP Sanglah Denpasar. Sari Pediatri, 17(6), 455-62.

Suriadji, D., Wati, D. K., Sidiartha, I., Suparyatha, I. B., \& Hartawan, I. (2017). Prevalence and association of cost and hospital malnutrition in Pediatric Intensive Care Unit Sanglah Hospital during 2015. Critical Care \& Shock, 20(1).

Ventura, J. C., Hauschild, D. B., Moreira, E. A. M., Pereira, L. C. R., Rosa, A. F., Barbosa, E., ... \& Moreno, Y. M. F. (2018). C-reactive protein/albumin ratio is associated with lung function among children/adolescents with cystic fibrosis: a three-year longitudinal study. Sao Paulo Medical Journal, 136(1), 29-36.

World Health Organization. (2014). C-reactive protein concentrations as a marker of inflammation or infection for interpreting biomarkers of micronutrient status. Vitamin and Mineral Nutrition Information System, pp. 1-4.

Sidiartha, I. G. L., Wati, D. K., Subanada, I. B., \& Suwarba, I. G. N. M. (2020). High C-reactive protein/albumin ratio increased risk of acute malnutrition during hospitalization in pediatric patients. International Journal of Health Sciences, 4(3), 32-38. https://doi.org/10.29332/ijhs.v4n3.453 


\section{Biography of Authors}

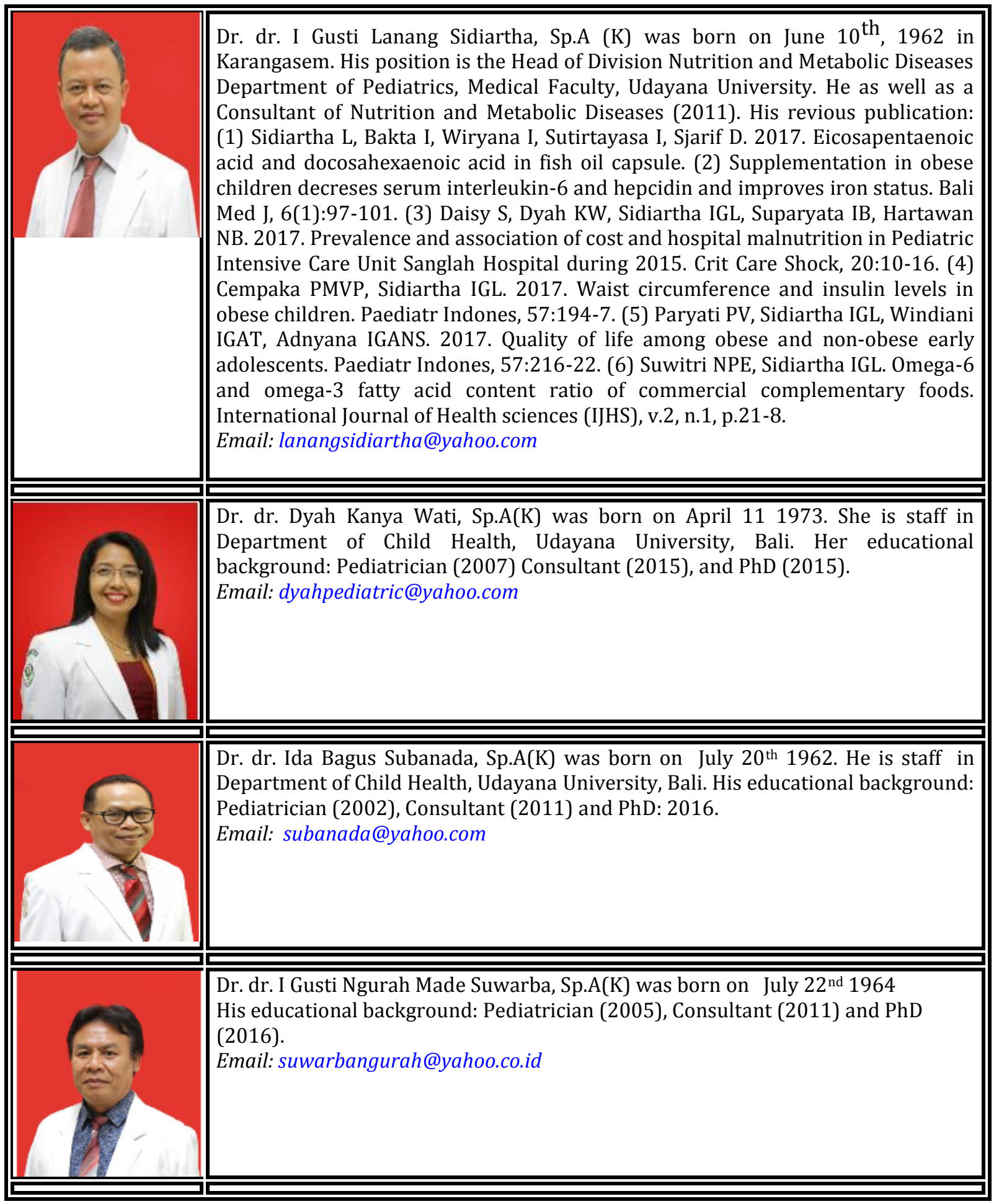

